\title{
Chemical Removal of Cordon Bunches in Dried Grape Production
}

\author{
D.J. Unwin, D.P. Singh, E.A. Hancock, M.O. Downey* \\ Department of Primary Industries Victoria, PO Box 905, Mildura, VIC 3502, Australia
}

Submitted for publication: May 2011

Accepted for publication: November 2011

Key words: Calcium nitrate, Ethrel ${ }^{\circledR}$, dried grape, Carina Currant, Sunmuscat, Sultana

\begin{abstract}
The Shaw swing-arm trellis has increased mechanisation in dried grape production as it enables trellis drying of the grapes in the vineyard. However, cordon bunches that do not dry reduce the quality of dried fruit at harvest. Traditionally, foliar application of ammonium nitrate was used to remove cordon bunches, but results were inconsistent. In recent years, health and safety concerns have heavily restricted the use of ammonium nitrate in the agricultural sector. Use of alternate chemical treatments was investigated to find an alternative to ammonium nitrate for removal of cordon bunches in Carina Currant, Sultana and Sunmuscat dried grape production. Different doses of calcium nitrate and Ethrel $^{\circledR}(21.7 \%$, w/v, ethephon) were applied to grapevines at various stages of vine growth. Calcium nitrate applied at a rate of $2.6 \%$ (w/v) to the vine pre-bloom at the 6 to 8 leaf stage (LS) and $250 \mathrm{ppm}$ Ethrel ${ }^{\circledR}$ applied at full bloom (10 to 12 LS) achieved the most effective results. Both treatments provide a cost effective alternative to ammonium nitrate without any significant negative impact on growth, fruit bearing of vines and yield in the following year. Separate application scheduling of calcium nitrate (at pre-bloom) and Ethrel ${ }^{\circledR}$ (at full-bloom) offers flexibility in spray (application) schedules a management practices.
\end{abstract}

\section{INTRODUCTION}

One of the keys to the ongoing success of dried grape production is the reduction of high labour costs through mechanisation. The utilisation of the Shaw swing-arm trellis in Australia minimised the need for labour intensive activities, replacing them with efficient mechanical technology. Mechanisation of winter pruning (hand assisted), harvest pruning (cane cutting), leaf stripping, trellis drying and machine harvesting are the major advances contributing to increased efficiency (Shaw et al., 2000). The key to mechanical harvesting is the swing-arm trellis, which enables drying in the vineyard through cane cutting and harvesting. Wires clamp the fruit bearing canes, holding them to the trellis during both operations (Shaw et al., 2000). Grape bunches above the cutting point of the fruiting canes remain connected to the vine and are not dried. These bunches "contaminate" the dried grapes as the harvester removes both dried and undried fruit which reduces the quality and value of the harvest. Reports suggest the amount of wet fruit contamination varies between $8-20 \%$, depending on the variety (Australian Dried Grape Association, 2005).

The removal of cordon bunches that remained connected to the vine is vital to the success of mechanisation of dried grape production on swing-arm trellis. Abscission of bunches within a grapevine canopy was achieved using ammonium nitrate (Zabadal et al., 1996). This practice was adapted for use in the Australian dried grape industry, but incorrect timing and/or application rate caused inconsistent results (Mollah \& Krstic, 2000). Due to supply restrictions of ammonium nitrate, optimisation was not pursued and research encouraged to develop an alternative chemical spray regime for the removal of cordon bunches.

Several plant growth hormones and fertilisers have demonstrated berry thinning effects on grapevines over a range of development stages (Weaver \& Pool, 1971a; Weaver, 1975; Sarooshi \& Roberts, 1979; May, 2004). Plant hormones, for example gibberellins (GAs), cytokinins and auxins have been shown to promote or inhibit flowering and fruit-set. GAs, which play a vital role in overall plant development (Swain \& Singh, 2005), promotes formation of the anlagen and the growth of tendrils, but inhibits the growth of the inflorescence primordia (Srinivasan \& Mullins, 1980; Boss \& Thomas, 2002). With the introduction of the trellis drying technique, GAs were employed as bunch thinning sprays to improve penetration of drying oil and reduce oxidative browning in berries (Lynn \& Jensen, 1966; Sarooshi \& Roberts, 1979). However, application of GAs

*Corresponding author: mark.downey@dpi.vic.gov.au [Fax: +61350514523]

Acknowledgements: Funds for this project were provided by Horticulture Australia Limited, the Australian Dried Fruits Association and the Victorian Department of Primary Industries. The authors would like to acknowledge participating growers for allowing the project team to conduct trials on their vineyards. The authors would also like to acknowledge past project leaders Dr Mahabubur Mollah (DPI-Horsham) and Alison McGregor (formerly DPI-Mildura); as well as Jenny Gordon (DPI-Mildura), who undertook sample collection and processing and Debra Partington (DPI-Hamilton), who assisted with statistical analyses and interpretation of results. 
can reduce shoot numbers in the following season by causing bud necrosis (May, 2004).

The use of Cytokinins stimulated bud initiation and inflorescence primordia formation, as well as growth of lateral buds due to loss of apical dominance (Srinivasan \& Mullins, 1980; Raven et al., 1992; Salisbury \& Ross; 1992). Application of cytokinins promoted flowering (Tse et al., 1974) and increased berry set (Weaver et al., 1965). Limitations on the commercial use of cytokinins include its cost and difficulties associated with its application (May, 2004); and based on previous studies, would be contrary to the objective of low cost removal of cordon bunches.

Auxins regulate many physiological processes such as root initiation, vascular tissue differentiation and fruit development (Levetin \& McMahon, 1999). Their application, depending on rate, has been demonstrated to inhibit or promote leaf and fruit abscission and induce fruit-set as well as delay ripening of berries (Levetin \& McMahon, 1999). The role of auxins in ethylene production (Salisbury \& Ross, 1992) has been exploited by the horticulture industry (apples, oranges, tomato and grapefruit) to facilitate harvesting through coordinated abscission of fruits (Levetin \& McMahon, 1999). Synthetic auxins such as 3 -chlorophenoxy- $\alpha$-propionamide (3-CPA) and 4-chlorophenoxyacetic acid (4-CPA) at 1,000 ppm applied pre-bloom, full-bloom, fruit-set or post-set resulted in the most effective berry removal and bunch disruption in Sultana grapes, Vitis vinifera L. cv. Sultana (Weaver \& Pool, 1971a). Rahemi and Ramezanian (2007) have also reported use of naptheleneacetic acid (NAA), a synthetic auxin, to successfully thin fruit in pistachio nuts, Pistacia vera $\mathrm{L}$. There is limited information on the use of auxins in commercial applications and a substantial amount of research would be required to develop auxins for a spray application without the risk of negative whole plant effects (May, 2004).

Stress associated plant hormones such as salicylic acid, ethylene and abscisic acid (ABA) have also been used to control fruit-set in the dried grape industry, but with limited success. For example, salicylic acid, an endogenous signal mediating plant defense response against pathogens (Shah, 2003), has been used for flower and fruit thinning in Sultana at pre-bloom, bloom, fruit-set and post fruit-set (Weaver \& Pool, 1971a). Applications of salicylic acid at fruit-set and post fruit-set resulted in $100 \%$ berry loss, while $90 \%$ berry loss was achieved when salicylic acid was applied at full bloom at a rate of 4,000 ppm. In less effective treatments, surviving berries had ring scars and tissue necrosis which reduced overall fruit quality (Weaver \& Pool, 1971a).

Ethylene, naturally produced in the grapevine as a gas, is synthesised from the amino acid methionine in most plant tissues during ripening or senescence and in response to stress (Raven et al., 1992). Ethephon, a commercially available chemical which breaks down to ethylene in plants, was successfully used to thin mandarin (Citrus reticulate cv. Imperial and Beauty of Glen Retreat) at 250 ppm (Chapman, 1980) and pistachio fruitlets at 100 and 200 ppm (Rahemi \& Ramezanian, 2007). Published data indicate that the timing and rate of ethephon applications were important to manipulate berry set. Naito et al. (1985) used Ethrel $^{\circledR}$ (trade name for ethephon) to over-thin berries in Muscat of Alexandria (Vitis vinifera L.) at full bloom (50 ppm). Szyjewicz and Kliewer (1983), used 750 ppm Ethrel ${ }^{\circledR}$ applications at and post flowering on Chenin blanc (Vitis vinifera L.) and found that applications up to two weeks post flowering removed all inflorescences.

A range of herbicides that disrupt the action of key plant growth hormones have also been shown to thin berries in grapevines over a range of flower and berry development stages (Weaver \& Pool, 1969; Zabadal et al. 1996; Mollah \& Krstic, 2000). Morphactin (an inhibitor of auxin transport) applied at 1,000 ppm to Sultana pre-bloom, at bloom or at fruit-set resulted in more than $90 \%$ berry drop (Weaver \& Pool, 1968; 1971b). The impact of morphactin on grapevine berry set was blocked when auxins were applied exogenously but application rates of morphactin greater than $100 \mathrm{ppm}$ reduced vegetative growth of the whole vine (Weaver \& Pool, 1969).

As mentioned earlier, plant hormones are not only difficult to use as sprays but have undesirable impacts on subsequent vine performance. It is possible that levels and timing of applications need to be optimised due to the broader roles plant hormones play in overall plant development. To improve the efficiency of dried grape production, it is important to resolve these issues and develop new management practice(s) to improve efficiency and fruit quality.

This study investigated whether the timing or rate of application of plant hormones (ethylene and NAA) was effective in cordon bunch removal and if there were negative side effects. Various chemical salts and fertilizers such as calcium nitrate, ammonium nitrate, urea and sodium chloride were also evaluated as spray treatments to remove cordon bunches. Rates and timing of applications of these chemicals were investigated and their efficacy in the removal of unwanted cordon bunches, and impact on subsequent vine growth, is reported here.

\section{MATERIALS AND METHODS \\ Chemicals}

Naphthaleneacetic acid (NAA), a synthetic auxin, marketed as "Stop Drop" was supplied by Kendon Chemical and Manufacturing Company Pty. Ltd. (Thornbury, Victoria, Australia). Gibberellic Acid (GA) marketed as ProGibb G.A. was purchased from Valent BioSciences Corporation, (Libertyville, Illinois, USA). Ethre ${ }^{\circledR}$ was acquired from Bayer CropScience Pty. Ltd. Vic. Australia). Ethrel ${ }^{\circledR}$ is currently registered for some viticultural applications; however it is not currently registered, or permitted, for commercial application in the removal of cordon bunches in dried grape production in Australia. Urea low in biuret, marketed as Lo-Bi Urea, was acquired from Paton Fertilisers Pty. Ltd. Penrith, (NSW, Australia). Calcium nitrate (greenhouse grade) was supplied by Campbells Fertiliser Australasia Pty. Ltd. (Vic., Australia). Calcium nitrate was applied under permit and is currently not a registered agricultural chemical product for use on dried grapes in Australia. Sodium chloride Irrigation Solution was purchased from Pfizer Pty. Ltd. (Perth, WA, Australia). Ammonium nitrate was obtained from Paton Fertilisers Pty. Ltd. (Penrith, NSW, Australia). An ammonium nitrate-urea (low biuret) fertiliser marketed 
as N-Blast $42^{\circledR}$ was supplied by Spraygro Liquid fertilisers Pty. Ltd. (Gillman, SA Australia). Agral ${ }^{\circledR}$ was obtained from Syngenta Crop Protection Pty. Ltd. (North Ryde, NSW Australia).

\section{Preliminary evaluation of potential plant hormones and chemicals for cordon bunch removal}

Initial field trials were designed to explore plant hormone and chemical treatments as possible alternatives to ammonium nitrate for cordon bunch removal. Urea is a constituent of N-blast $42^{\circledR}$ along with ammonium nitrate and was included as a spray in the hormone trial to further investigate whether urea plays any role in cordon bunch removal. Ethrel ${ }^{\circledR}$ (21.7\% ethephon), auxin (NAA), and urea were applied to Sunmuscat (on rootstock 1103-Paulsen) at a field site located at South Merbein in the Sunraysia region of Victoria $\left(34^{\circ} 12^{\prime} \mathrm{S}, 142^{\circ} 01^{\prime} \mathrm{E}\right)$ using a Triggs Trellis Supplies Pty. Ltd. customised high volume/low pressure recirculating spray unit. The treatments consisted of $500 \mathrm{ppm}$ and 2000 ppm Ethrel ${ }^{\circledR}, 30$ ppm NAA, 500 ppm Ethrel ${ }^{\circledR}$ applied with $30 \mathrm{ppm}$ NAA and a $6 \%(\mathrm{w} / \mathrm{v})$ urea treatment using four replicates on three dates, 2005/10/14 (pre-flowering or 3 to 5 leaf stage), $2005 / 10 / 28$ (pre-flowering or 6 to 8 leaf stage) and 2005/11/16 (full bloom or 13 to 16 leaf stage) with $\operatorname{Agral}^{\circledR}(1 \mathrm{~mL} / \mathrm{L})$ as the wetting agent. Each treatment was assessed 6 to 8 weeks after application by hand removal of any remaining cordon bunches from the spray zone. Removed bunches were weighed and results were represented as $\mathrm{kg} / \mathrm{m}$ of cordon.

In order to investigate chemical fertiliser(s) as potential cordon bunch removal sprays, four different treatments were applied to a commercial block of Carina Currant (Ramsey rootstock) located near South Merbein in the Sunraysia region of Victoria $\left(34^{\circ} 12^{\prime} \mathrm{S}, 142^{\circ} 01^{\prime} \mathrm{E}\right)$, during the 2005 06 growing season. The fertiliser treatments consisted of ammonium nitrate $(1.75 \% \mathrm{w} / \mathrm{v})$, N-blast $42^{\circledR}(2.3 \% \mathrm{v} / \mathrm{v}$; an ammonium nitrate/urea based fertiliser), calcium nitrate $(2.8 \% \mathrm{w} / \mathrm{v})$ and sodium chloride $(1.2 \% \mathrm{w} / \mathrm{v})$ applied with $\operatorname{Agral}^{\circledR}(1 \mathrm{~mL} / \mathrm{L})$ as the wetting agent. Untreated vines were included in the trial as a control with adequate buffer zones separating each treatment. Off label use of calcium nitrate was conducted under permit number PER10210 issued by the Australian Pesticides and Veterinary Medicines Authority (APVMA). Each treatment was applied at the 6 to 8 leaf stage (LS) in October 2005 (using a customised spray unit described above). Twelve replicates of each treatment (including control) were applied to the Carina Currant trial site. Prior to harvest pruning (cane cutting), the cordon fruit from each treatment was removed by hand and the fresh weight of the fruit was recorded in kilograms per metre of cordon $(\mathrm{kg} / \mathrm{m})$. The following season (2006-07), dried fruit yield was monitored to assess any carry-over effects from each of the treatments. This was achieved by hand removal of a half vine transect for each treatment coinciding with the commercial harvest of the trial site. Bunch numbers and dry weight were recorded $(\mathrm{kg} / \mathrm{m})$. Dry weight was adjusted to the industry standard of $13 \%$ moisture which is ideal for stable colour within the dried berries (Australian Dried Fruits Association, 2005). A dried fruit moisture tester
(Dried Fruit Association, California, Serial No. A 902) was used according to the manufacturer's instructions to measure the electrical conductance, hence the moisture content in the dried fruit samples (Downey et al., 2008).

\section{Ethylene application}

A large scale trial was conducted to further develop ethylene as an alternative treatment for cordon bunch removal. Ethrel ${ }^{\circledR}$ was applied to three field sites. A Sunmuscat (1103-Paulsen rootstock) site located near South Merbein in the Sunraysia region of Victoria (34 $12^{\prime} \mathrm{S}, 142^{\circ} 01^{\prime} \mathrm{E}$ ), a Sultana (on Ramsey rootstock) site located at Lake Hawthorn in the Sunraysia region of Victoria $\left(34^{\circ} 12^{\prime} \mathrm{S}, 142^{\circ} 05^{\prime} \mathrm{E}\right)$ and a Carina Currant (Ramsey rootstock) field site located near Cabarita in the Sunraysia region of Victoria $\left(34^{\circ} 11^{\prime} \mathrm{S}, 142^{\circ} 05^{\prime} \mathrm{E}\right)$. Five treatments were replicated four times and applied in a random trial design with buffer zones. An untreated control and treatments of $250 \mathrm{ppm}$ and $500 \mathrm{ppm}$ were applied over two dates to coincide with the 10 to 12 leaves open stage (LS) $(2006 / 10 / 20)$ and 15 to 16 LS (2006/11/10) growth stages of the grapevines. All treatments were applied using a Triggs Trellis Supplies Pty. Ltd. customised high volume/ low pressure recirculating spray unit with $\operatorname{Agral}^{\circledR}(1 \mathrm{~mL} / \mathrm{L})$ as the wetting agent. The effectiveness of Ethrel ${ }^{\circledR}$ was assessed by the harvested weight of cordon fruit at maturity. Dry yield $(\mathrm{kg} / \mathrm{m})$ was monitored for any change with respect to the control due to treatments by hand harvesting a half vine transect. Weights were adjusted to a moisture content of $13 \%$ (Australian Dried Fruits Association, 2005) and compared to control treatments.

\section{Calcium nitrate optimisation trial}

A trial was conducted on a commercial block of Carina Currants (Ramsey rootstock) located near Merbein in the Sunraysia region of Victoria $\left(34^{\circ} 10^{\prime} \mathrm{S}, 142^{\circ} 03^{\prime} \mathrm{E}\right)$ to optimise calcium nitrate spray application to remove cordon bunches. Calcium nitrate was applied at three different rates; $2.5 \%$ $(\mathrm{w} / \mathrm{v}), 3.3 \%(\mathrm{w} / \mathrm{v}), 4.1 \%(\mathrm{w} / \mathrm{v})$ with $\operatorname{Agral}^{\circledR}(1 \mathrm{~mL} / \mathrm{L})$ as a wetting agent. Untreated vines were included as a control. The applications were applied using a Triggs Trellis Supplies Pty. Ltd. customised high volume/low pressure recirculating spray unit on five different dates; 3 to 5 LS (2005/10/11), 4 to $7 \mathrm{LS}(2005 / 11 / 16), 6$ to $10 \mathrm{LS}(2005 / 10 / 23), 7$ to $11 \mathrm{LS}$ $(2005 / 10 / 30)$ and 13 to $16 \operatorname{LS}(2005 / 11 / 8)$. To reduce damage to growing tips on replacement canes, which are the fruit producing canes for the following season, only lower rates of calcium nitrate were applied on the first three application dates. Higher rates were used at the later dates based on industry assumptions that higher levels of calcium nitrate would be needed to remove older more lignified inflorescences. Spray assessments were conducted 10 weeks after application by hand removal of cordon bunches. Weights were recorded as $\mathrm{kg} / \mathrm{m}$. Harvest data was collected on dried fruit yield from each treatment site in the following two seasons (2006-07 and 2007-08) to determine whether the more concentrated treatments effected the yield in subsequent years. Dry weight $(\mathrm{kg} / \mathrm{m})$ was adjusted, by calculation to the industry moisture standard of 13\% (Australian Dried Fruits Association, 2005). 


\section{Diurnal application to enhance effectiveness of calcium nitrate}

In order to enhance the efficacy of calcium nitrate as a spray to remove cordon bunches in Sunmuscat and Carina Currants, two trials were conducted. One on a Sunmuscat (1103-Paulsen rootstock) field site located near South Merbein in the Sunraysia region of Victoria (34 $12^{\prime}$ 'S, $142^{\circ} 01^{\prime} \mathrm{E}$ ) and a second on a Carina Currant (Ramsey rootstock) site located near Cabarita in the Sunraysia region of Victoria $\left(34^{\circ} 11^{\prime} \mathrm{S}, 142^{\circ} 05^{\prime} \mathrm{E}\right)$. Each trial site consisted of eight replicates of each treatment (including an untreated control). The eight replicates were factored into a random trial design. Relative humidity, temperature and wind speed were recorded at each field site using a Kestrel ${ }^{\circledR} 3500$ weather station (Kestrel Weather Australia, Mt Eliza, Vic. Australia) to investigate the effect of diurnal variation on cordon bunch removal (Table 1). Treatments were applied at 08:00, 15:00 and 22:00 when the vines had reached the 7 to $8 \mathrm{LS}$. All treatments were $2.6 \%(\mathrm{w} / \mathrm{v})$ calcium nitrate applied using Triggs Trellis Supplies Pty. Ltd. (Mildura, Australia) customised high volume/low pressure spray unit with $1 \mathrm{~mL} / \mathrm{L} \mathrm{Agral}{ }^{\circledR}$ as wetting agent. The cordon fruit was hand removed from a half vine transect at maturity $\left(21^{\circ} \mathrm{Brix}\right)$ and weighed. Yield data was collected from dried fruit hand harvested from target vines (half vine transect) to determine if the application had an effect on dried fruit yield $(\mathrm{kg} / \mathrm{m})$. The moisture content of the fruit was adjusted via calculation to the industry standard of 13\% (Australian Dried Fruits Association, 2005).

\section{Statistical analysis}

Data collected from all the trials were subjected to analysis of variance (ANOVA- Genstat $12^{\text {th }}$ Edition, VSN International Ltd., UK). Significant differences between means were identified using the least significant difference (LSD).
Correlations were identified by the Pearson product-moment correlation coefficient (r) with a two sided test.

\section{RESULTS}

Screening of plant growth hormones and chemical fertilisers for the removal of cordon bunches

In 2005, a trial was developed to investigate the possible use of plant growth regulators (hormones) and chemical fertilisers to induce abscission of cordon bunches. Data showed that Ethrel ${ }^{\circledR}$ had potential for use as a cordon bunch removal treatment (Table 2). The most effective treatment for removal of cordon bunches from Sunmuscat was Ethrel ${ }^{\circledR}$ when applied at full-bloom (13 to $16 \mathrm{LS})$. When applied pre-flowering (6 to $10 \mathrm{LS}$ ), the $500 \mathrm{ppm}$ Ethrel $^{\circledR}$ treatment removed $41.8 \%$ of the cordon fruit compared to the control, while 2000 ppm Ethrel ${ }^{\circledR}$ applied at that time removed 85.5\% compared to the control (fresh weight $\mathrm{kg} / \mathrm{m}$ ). By comparison, the same treatments applied at full-bloom removed 90.8 and $98.7 \%$ of fruit respectively. Combined treatment of synthetic auxin (30 ppm NAA) and 500 ppm of Ethrel ${ }^{\circledR}$ sprayed at 2005/11/16 (full bloom) was also effective at removing cordon bunches, however it was less effective than Ethrel ${ }^{\circledR}$ alone. NAA and urea treated vines had significantly $(\mathrm{p}<0.01)$ higher cordon fruit bunch weights $(\mathrm{kg} / \mathrm{m})$ compared to Ethrel $^{\circledR}$ (Table 2). The results indicated that the removal of cordon bunches using NAA was dependant on the growth stage of the vines. The most effective NAA treatment was that applied at full bloom, which removed $36.8 \%$ of cordon fruit relative to the control. Both NAA and urea were found to be unsuitable as cordon bunch removal treatments when applied close to full bloom. Therefore, these two chemicals were not factored into future trials.

Results obtained from a trial in the 2005-06 season, to screen chemical salts (many of which are common fertilisers) as sprays for the removal of cordon bunches, indicated that

\section{TABLE 1}

Microclimate data for Sunmuscat and Carina Currant field sites at time of treatment application, six to eight leaf stage (2007/10/20). Wind speed for whole site, temperature and relative humidity for each field replicate. Values represent mean SE ( $\mathrm{n}=8$ ).

\begin{tabular}{ccccc}
\hline Time $(\mathbf{h})$ & Variety & Wind $\mathbf{( k m} / \mathbf{h})$ & Temperature $\left({ }^{\mathbf{0}} \mathbf{C}\right)$ & Relative humidity $(\mathbf{\%})$ \\
\hline $08: 00$ & Sunmuscat & 10.3 & $22.2 \pm 0.2$ & $39.8 \pm 0.5$ \\
$15: 00$ & Sunmuscat & 13.9 & $34.5 \pm 0.1$ & $18.2 \pm 0.3$ \\
$22: 00$ & Sunmuscat & 0.0 & $15.2 \pm 0.2$ & $73.9 \pm 1.4$ \\
$8: 00$ & Carina Currant & 16.8 & $13.8 \pm 0.2$ & $65.5 \pm 0.8$ \\
15:00 & Carina Currant & 18.0 & $22.4 \pm 0.1$ & $31.1 \pm 0.2$ \\
$22: 00$ & Carina Currant & 0.0 & $13.2 \pm 0.2$ & $60.5 \pm 0.7$ \\
\hline
\end{tabular}

SE-standard error

\section{TABLE 2}

Fruit remaining on cordon after Ethrel ${ }^{\circledR}$, auxin and urea treatments to remove cordon bunches. Data for all the treatments was collected at harvest time i.e. December, 2005. The treatments consisted of 500ppm and 2000ppm Ethrel ${ }^{\circledR}, 500 \mathrm{ppm} \mathrm{Ethrel}{ }^{\circledR}$ in combination with 30ppm ml/L NAA, 30ppm NAA and $6 \%(\mathrm{w} / \mathrm{v})$ Urea. The values are mean $\pm \mathrm{SE}(\mathrm{n}=4)$ of cordon bunch weight $(\mathrm{kg} / \mathrm{m})$ at harvest. $\mathrm{LS}=$ Leaf stage, Pre-bloom $=6$ to $8 \mathrm{LS}$, full bloom $=10$ to $12 \mathrm{LS}$.

\begin{tabular}{|c|c|c|c|c|c|c|}
\hline $\begin{array}{l}\text { Treatment dates } \\
\text { (LS stage) }\end{array}$ & Control & $\begin{array}{c}\text { Ethrel }^{\circledR} \\
500 \text { ppm }\end{array}$ & $\begin{array}{c}\text { Ethrel }^{\circledR} \\
\text { 2000ppm }\end{array}$ & $\begin{array}{c}\text { NAA 30ppm / } \\
\text { Ethrel }^{\circledR} \text { 500ppm }\end{array}$ & NAA 30ppm & Urea $6 \%$ \\
\hline $2005 / 10 / 14(3-5)$ & $0.76 \pm 0.1$ & $0.55 \pm 0.1$ & $0.26 \pm 0.08$ & $0.41 \pm 0.12$ & $0.78 \pm 0.12$ & $0.54 \pm 0.11$ \\
\hline $2005 / 10 / 28(6-11)$ & & $0.45 \pm 0.1$ & $0.11 \pm 0.04$ & $0.48 \pm 0.14$ & $0.60 \pm 0.11$ & $0.76 \pm 0.15$ \\
\hline $2005 / 11 / 05(13-16)$ & & $0.07 \pm 0.04$ & $0.01 \pm 0.01$ & $0.14 \pm 0.07$ & $0.48 \pm 0.05$ & $0.51 \pm 0.04$ \\
\hline
\end{tabular}

SE-standard error 
ammonium nitrate, calcium nitrate and $\mathrm{N}$-blast $42^{\circledR}$ were all effective in removal of cordon bunches (Fig. 1). Although sodium chloride was an effective treatment, it was less effective than the other chemicals trialled. Sodium chloride removed $50 \%$ of cordon bunches as compared to $80 \%$ with other treatments. Of all the chemical salt treatments, calcium nitrate appeared to be the most effective. Dried grape yields of vines $(\mathrm{kg} / \mathrm{m})$, in the following season (2006-07), were assessed to determine the carry-over effect of the salt treatments (Fig. 2). No significant variation was observed in the dried fruit yields of any of the treatments compared with the control, indicating that these treatments did not affect bud initiation or bud fertility.

\section{Optimising Ethrel ${ }^{\circledR}$ and calcium nitrate application}

Following analysis of the results from the 2005-06 season (Table 2), field trials were initiated in the 2006-07 season to determine the optimum application rate and timing of Ethre $^{\circledR}$. Similarly, calcium nitrate application timing and rates were optimised by conducting a field trial, in season 2005-06, parallel to the one described above for screening of various salts for cordon bunch removal.

Ethrel $^{\circledR}$ treatments in 2006-07 on Sunmuscat, Sultana and Carina Currant favoured application at the 10 to 12 LS

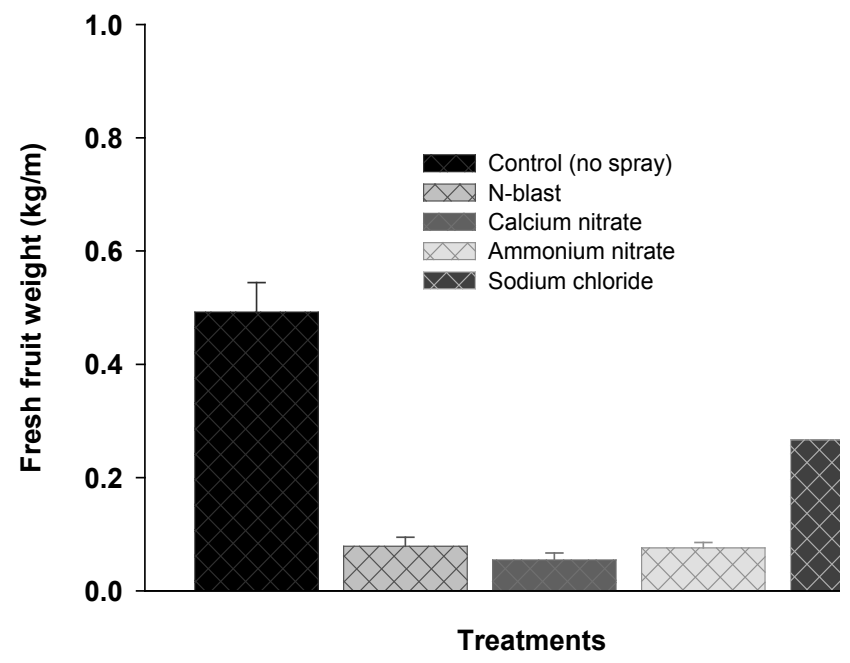

FIGURE 1

Effect of different chemical salt treatments on fresh weight of cordon fruit at harvest $(\mathrm{kg} / \mathrm{m})$ of Carina currant. The data was compared with an unsprayed control to determine effectiveness of the different applications in abscising cordon bunches in 2005-06. Values represent mean $\pm \operatorname{SE}(n=4)$.

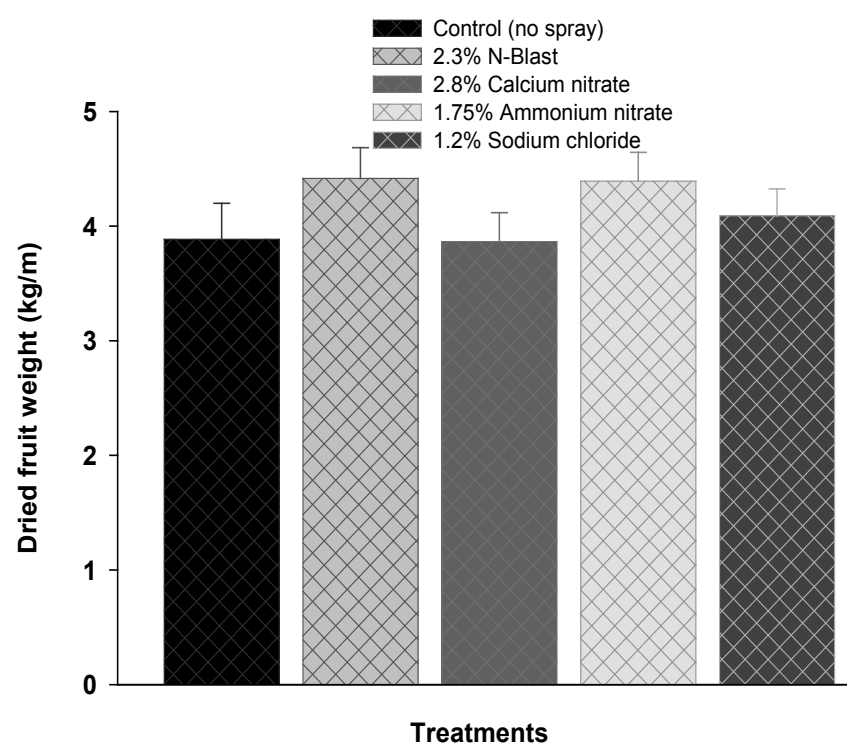

FIGURE 2

Effect of various chemical salts on dried fruit yields $(\mathrm{kg} / \mathrm{m})$ of Carina currant in 2006-07 season following the cordon bunch removal treatments in the 2005-06 season.

coinciding with full bloom (Fig. 3). All treatments at this stage were significantly more effective in cordon bunch removal compared to other stages of vine development. Both the $250 \mathrm{ppm}$ and $500 \mathrm{ppm}$ rates tested at the 10 to 12 LS proved effective. Follow up vine and yield monitoring in the next season (2007-08) indicated that Ethrel ${ }^{\circledR}$ treatment did not affect dried grape yield or vine health in any of the cultivars tested (Fig. 4).

Cordon fruit data (Table 3) collected at maturity after calcium nitrate applications at different stages of vine growth showed that applications between 4 LS (2005/10/16) and 10 LS (2005/10/23) removed most of the fruit from the cordon zone. Earlier and later applications of calcium nitrate had limited effect in cordon bunch removal. The optimum removal of cordon bunches was achieved with application between $6 \mathrm{LS}$ and $8 \mathrm{LS}$ at a rate between $1.75 \%$ and $3.3 \%(\mathrm{w} / \mathrm{v})$ of calcium nitrate. While the best results in terms of cordon bunch removal (Fig. 1 and Table 3) were achieved with calcium nitrate application two weeks prior to flowering, anecdotal evidence suggested that timing during the diurnal cycle was also critical. This was based on a perceived impact of changes in relative humidity throughout the diurnal cycle influencing the drying rate of treatment sprays. Impact of diurnal cycle on efficiency of calcium

TABLE 3

Effect of calcium nitrate application on the fresh weight $(\mathrm{kg} / \mathrm{m})$ of fruit remaining on the cordon of Carina Currant at harvest. Fruit was harvested in December, 2005, around 10 weeks after application of Calcium nitrate. Values present mean $\pm \mathrm{SE}$ ( $\mathrm{n}=4$ ). $\mathrm{NA}=$ no application on these dates. $\mathrm{LS}=$ Leaf stage, Pre-bloom $=6$ to $8 \mathrm{LS}$, full bloom $=10$ to $12 \mathrm{LS}$.

\begin{tabular}{lccccccc}
\hline $\begin{array}{l}\text { Treatmentdates } \\
\text { (LS stage) }\end{array}$ & Control & $\mathbf{1 \%}$ & $\mathbf{1 . 7 5 \%}$ & $\mathbf{2 . 5 \%}$ & $\mathbf{3 . 3 \%}$ & $\mathbf{3 . 7 5 \%}$ & $\mathbf{4 . 1 \%}$ \\
\hline $2005 / 10 / 05(3-5)$ & $0.56 \pm 0.08$ & $0.21 \pm 0.10$ & $0.16 \pm 0.08$ & $0.10 \pm 0.02$ & NA & NA & NA \\
$2005 / 10 / 16(4-7)$ & & NA & $0.06 \pm 0.02$ & $0.07 \pm 0.03$ & $0.05 \pm 0.03$ & NA & NA \\
$2005 / 10 / 23(6-10)$ & & NA & $0.05 \pm 0.02$ & NA & $0.04 \pm 0.01$ & $0.01 \pm 0.01$ & NA \\
$2005 / 10 / 30(7-11)$ & & NA & $0.10 \pm 0.03$ & $0.10 \pm 0.03$ & NA & $0.11 \pm 0.04$ & $0.09 \pm 0.04$ \\
$2005 / 11 / 08(13-16)$ & & NA & $0.37 \pm 0.05$ & $0.14 \pm 0.03$ & $0.35 \pm 0.04$ & $0.26 \pm 0.07$ & $0.14 \pm 0.03$ \\
\hline
\end{tabular}

SE-standard error 
(A) Sunmuscat

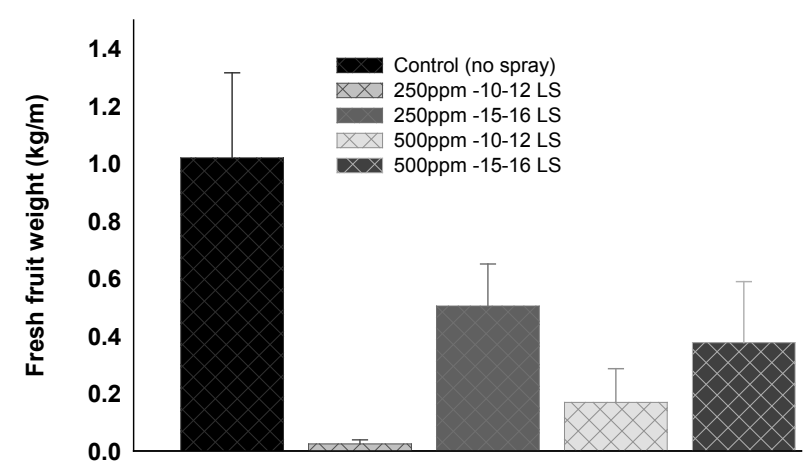

(B) Carina Currant

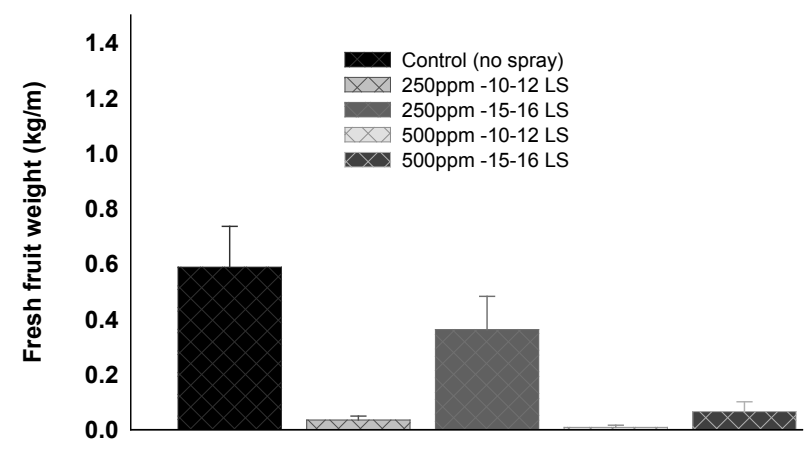

\section{(C) Sultana}

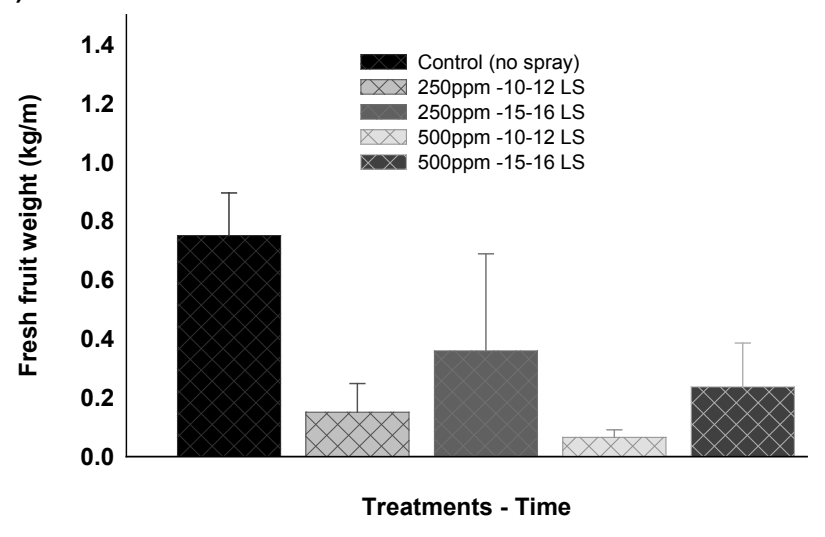

FIGURE 3

Effect of Ethrel ${ }^{\circledR}$ treatments on fresh weight of cordon fruit at harvest $(\mathrm{kg} / \mathrm{m})$ of Sunmuscat (A), Carina currant (B) and Sultana (C). Treatments of Ethrel ${ }^{\circledR}$ were applied at two different leaf stages (LS). Values represent mean $+\mathrm{SE}(\mathrm{n}=4)$.

nitrate spray as a cordon bunch removal treatment was evaluated for Sunmuscat and Carina Currant in the 2007-08 season. Data indicated that all treatments were effective in removing cordon bunches compared to the untreated control and that diurnal variance in application time had minimal impact on cordon bunch removal (Fig. 5). All applications of calcium nitrate had no effect on dried grape yield in future seasons.

\section{DISCUSSION}

Chemical applications to remove cordon bunches in trellis dried grape production have proven to be a popular management tool for reducing labour cost. Historically,

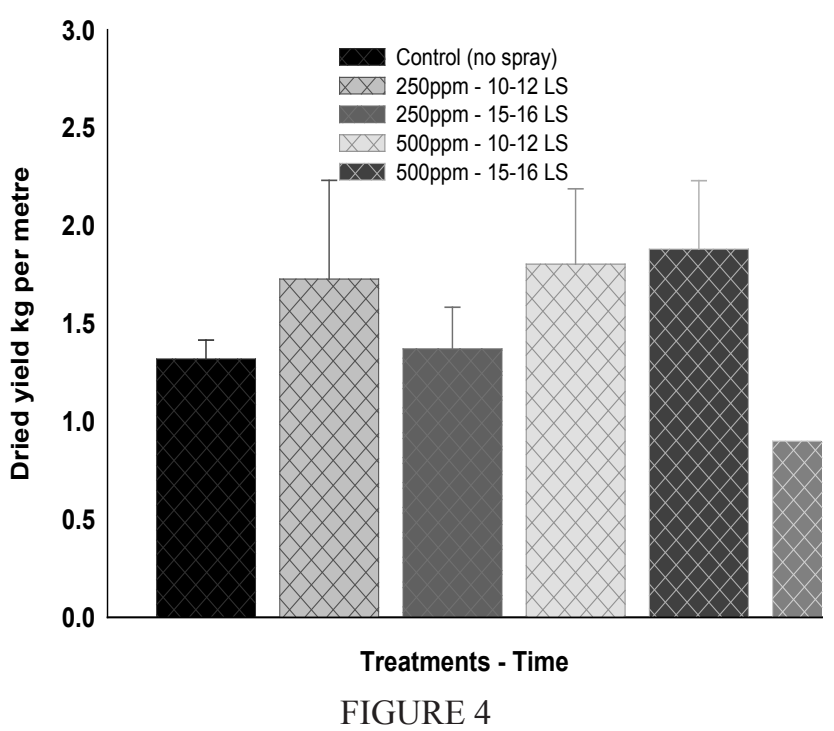

Effect of Ethrel $\AA$ spray treatments on dried fruit yield $(\mathrm{kg} / \mathrm{m})$ of Sunmuscat in 2007-08 season following the cordon bunch removal treatments in the 2006-07 season. Values represent mean $\pm \operatorname{SE}(n=4)$.

ammonium nitrate was widely used for this purpose. However, health and safety concerns, restricting the supply of ammonium nitrate, created a need for an alternative treatment for cordon bunch removal. Ammonium nitrate was compared to similar fertilisers (chemical salts) to determine their effect on cordon bunch removal. A range of chemicals, including plant growth hormones, were employed as sprays at different stages of vine development to determine their efficacy in the removal of cordon bunches in Sunmuscat, Sultana and Carina currants. Trials conducted during the 2005-06 and 2006-07 seasons indicated that calcium nitrate and Ethrel $^{\circledR}$ treated vines retained significantly fewer cordon bunches than vines subjected to other treatments.

Calcium nitrate and N-blast $42^{\circledR}$ yielded similar results, most likely due to fact that N-blast $42^{\circledR}$ is a combination of ammonium nitrate and urea (low-biuret). Ammonium nitrate appears to be the active cordon bunch removal chemical in N-blast $42^{\circledR}$, as urea was unsuccessful when trialled alone. The action of urea is different to that of other chemical fertilisers, in that urea accumulation is regulated by the plant nickel status. Marschner (1999) proposed that urea induced necrosis at leaf tips after foliar application was reduced in plants with an adequate supply of nickel. Although nickel status was not monitored in this study, it is possible that these vines had adequate nickel content resulting in poor efficacy outcome with urea application. Sodium chloride was not evaluated further, because it was 50\% less effective than the other investigated.

\section{Ethre ${ }^{\circledR}$ is an effective plant hormone for cordon bunch removal}

Numerous studies indicate that GAs, auxins, and ethylene play a vital part in crop manipulation. All three were tested along with urea to determine their effect on cordon bunch removal, vine health and yield. GA did not remove cordon bunches and caused the replacement canes in the following season to clump together which reduced yield 


\section{(A) Sunmuscat}

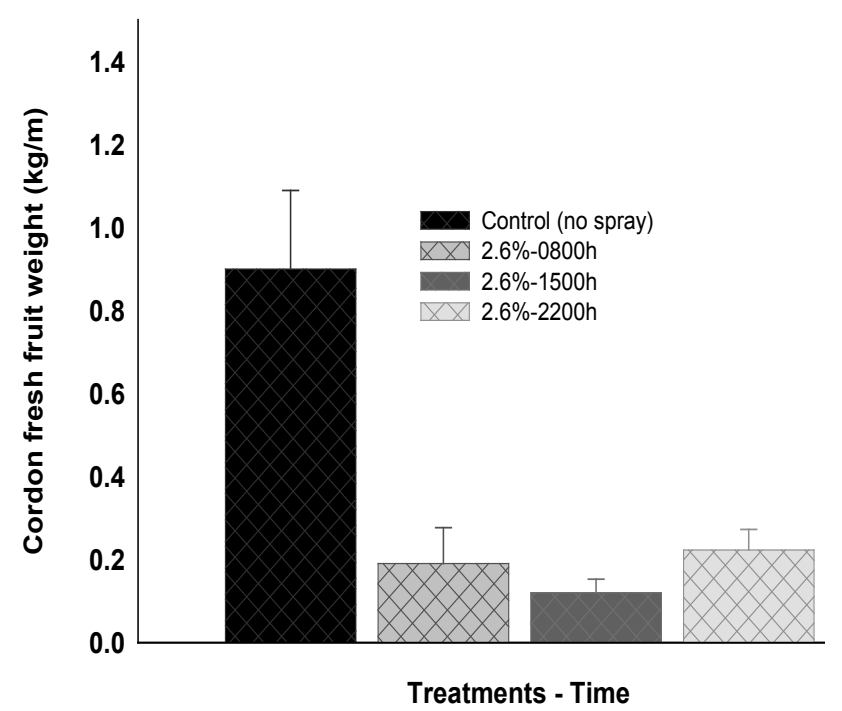

(B) Carina Currant

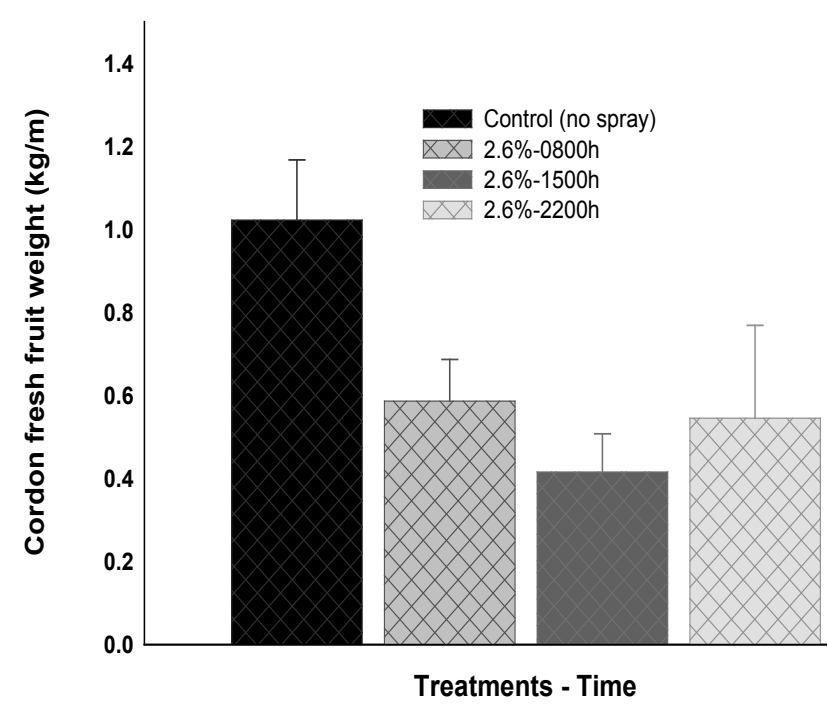

FIGURE 5

Impact of diurnal application of calcium nitrate on fresh weight of cordon fruit at harvest $(\mathrm{kg} / \mathrm{m})$ of Sunmuscat (A) and Carina Currant (B) after the cordon zone was treated with $2.6 \%(\mathrm{w} / \mathrm{v})$ calcium nitrate. The treatments were applied at 08:00, 15:00 and 22:00 $\mathrm{h}$ on the 2007/10/20 at the 6 to $10 \mathrm{LS}$. Values represent mean $\pm \mathrm{SE}(\mathrm{n}=8)$.

(data not shown). This was an unsatisfactory side-effect of GA application and hence, GA was not investigated further. The auxin trialled was NAA and was most effective when applied in combination with Ethrel $^{\circledR}$ (Table 2). This combination was not as effective as the Ethrel ${ }^{\circledR}$ treatment alone so NAA was not factored into further trials. Ethrel ${ }^{\circledR}$ was the most effective plant hormone treatment and formed the basis of the subsequent trials. The most effective trial involved the application of Ethre ${ }^{\circledR}$ at dates coinciding with full bloom i.e. 10 to 12 LS (Table 2). Weaver and Pool (1971b) made recommendations for Ethrel ${ }^{\circledR}$ in their work for use in crop removal in nursery stock where a crop would reduce vegetative growth. In this work, a similar result was achieved to that of Rahemi and Ramezanian (2007), where their work involved the use of Ethrel ${ }^{\circledR}$, NAA and urea as thinning agents in pistachio production. The outcome in both instances suggested that Ethrel ${ }^{\circledR}$ was a superior thinning agent to NAA and urea.

The results of the Ethrel ${ }^{\circledR}$ treatment on both Sunmuscat and Sultana showed Ethrel ${ }^{\circledR}$ was a successful replacement for ammonium nitrate in the removal of cordon bunches in trellis dried grape production. Ethrel ${ }^{\circledR}$ applied at the 10 to 12 LS (full bloom) at a rate of $250 \mathrm{ppm}$ was the most effective treatment for the removal of cordon bunches (Fig. 3). This result confirms the findings of Weaver and Pool (1971a) and Naito et al. (1985) who previously reported the crop removal properties of Ethrel $^{\circledR}$ while investigating various berry thinning agents. It should be noted that increasing the rate of Ethrel ${ }^{\circledR}$ resulted in a decrease in cordon bunch removal (Fig. 3). This reduction in cordon bunch removal could be attributed to changes in the internal pool and homeostasis of ethylene within the grapevine as a result of exogenous application of the ethylene at higher rates. This may also alter the function(s) of ethylene or other plant growth regulators. Recent research findings suggested that interaction between plant growth hormones is important to control overall plant growth (Swain \& Singh, 2005). Therefore, it will be interesting to investigate endogenous levels of ethylene and other plant growth regulators in vines and their impact on vine performance when higher rates of ethylene are applied exogenously.

\section{Calcium nitrate is an effective spray treatment between 6 and 8 leaf stage of vine growth}

Previous research reported variable success using ammonium nitrate for cordon bunch removal (Mollah \& Krstic 2000) and indicated that improved timing of the application and specific rates need to be identified. Optimising cordon bunch removal chemically reduces the need for manual labour to remove them. As with the application of ammonium nitrate, the most important aspect in the use of calcium nitrate was the timing of the application. The most effective timing in the 2005-06 season was a small window from the 6 to $8 \mathrm{LS}$ while the rate of application had minimal impact on the results (Table 3). This suggests that the grapevine inflorescence is damaged at a low level of calcium nitrate. Increasing the concentration of this chemical salt does not amplify its effect.

Investigation into the effects of calcium nitrate application on the dried grape yield in the 2005-06 season and the following season (2006-07) provided no evidence that calcium nitrate application at $2.6 \%(\mathrm{w} / \mathrm{v})$ reduced dried fruit yield (Fig. 2). This can be attributed to the fact that both calcium and nitrogen are required by the vine as macronutrients (Robinson 1988). In this study, when 2.6\% (w/v) calcium nitrate was applied to the vine, it was not detrimental to overall vine health.

Earlier studies indicated that damage to the inflorescences and fruit was most likely due to mass flow uptake through the organ's cuticle (Wittwer \& Teubner, 1959; Zabadal et al., 1996). Wittwer and Teubner (1959) observed that nutrient uptake was most rapid at night and early mornings at times of high relative humidity, suggesting that the timing of spray application was important in maximising the uptake of calcium nitrate, to achieve the desired outcome. However, the results achieved with calcium nitrate in this 
research did not confirm this (Fig. 5). Results obtained in the current study suggest that no diurnal variance existed in the effectiveness of cordon bunch removal. Cline and Bijl (2002) also concluded that the diurnal timing of thinning treatments in apples had no bearing on the results. This conclusion was further supported by an effective removal of cordon bunches during hot, dry and windy conditions (Tables 1). Baur and Schönherr (1995) noted that foliar applied nutrients were absorbed into the leaf through cuticles and open stomata. They also noted that increasing temperature improved the permeability of the cuticle and reduced the influence of stomatal activity.

The findings presented in this article may be extended to other horticulture crops. For example, calcium nitrate and Ethrel $^{\circledR}$ spray applications may be used in high percentage crop removal. Grape growers who cannot produce an economically viable crop may choose to "mothball" their vineyards by reducing inputs but retaining the vineyard for future use (McGuire \& Mould, 2009). Sommer et al. (2010) used Ethrel ${ }^{\circledR}$ to remove crop on Chardonnay (Vitis vinifera L.) vines under mothballing conditions and found that during that growing season, once the crop was removed, vine health was improved and water use was reduced.

\section{CONCLUSIONS}

The improvement in treatment strategies outlined in the current work for dried grape production, will offer producers greater profit margins and reduce their dependence on seasonal labour. The design of the Shaw swing-arm trellis allows access to the cordon while reducing the likelihood of the treatment affecting the fruiting zone. The data collected suggests that calcium nitrate $(2.6 \%)$ and $\operatorname{Ethrel}^{\circledR}(250 \mathrm{ppm})$ were the most suitable alternatives to ammonium nitrate for cordon bunch removal. Although these spray applications were equally effective in the removal of cordon bunches, the timing of optimal application of calcium nitrate and Ethrel ${ }^{\mathbb{R}}$ was at the 6 to 8 and the 10 to 12 LS respectively. Ethre ${ }^{\circledR}$ will be useful as a back-up to calcium nitrate treatment, should it not be possible to apply the chemical at the 6 to $8 \mathrm{LS}$ or if the application was to be unsuccessful. The spray regimes identified here provide flexibility in cordon bunch removal, which in turn will improve the efficiency of mechanised dried grape production.

\section{LITERATURE CITED}

Australian Dried Fruits Association, 2005. A Production guide for quality dried grapes (Mildura, Australia).

Baur, P., \& Schönherr, J., 1995. Temperature dependence of the diffusion of organic compounds across plant cuticles. Chemosphere 30, 1331-1340.

Boss, P.K. \& Thomas, M.R., 2002. Association of dwarfism and floral induction with a grape 'green revolution' mutation. Nature 416, 847-850.

Chapman, J.C., 1980. Ethephon for fruit thinning of Imperial and Beauty of Glen Retreat mandarins in the Central Burnett district, Queensland. Australian J. Exp. Agric. 20, 508-512.

Cline, J.A. \& Bijl, M., 2002. Diurnal spray timing does not affect the thinning of apples with carbaryl, benzyladenine, and napthaleneacetic acid. Canadian J. Plant Sci. 82, 437-441.
Downey, M.O., \& Hancock, E.A. 2008. Cordon bunch removal project for trellis dried grapes, Final Report for Horticulture Australia Limited, Department of Primary Industries Victoria, pp.1-56.

Downey, M.O., Pitt K.M. \& Hancock, E.A., 2008. Evaluation of new rootstocks for dried sultanas, Final Report for Horticulture Australia Limited, Department of Primary Industries Victoria, pp.1-71.

Levetin, E. \& McMahon, K., 1999. Plant Life Cycle: Fruits and Seeds. In Plants and Society. WCB McGraw-Hill, Madison, Wisconsin. pp. 86-98.

Lynn, C.D. \& Jensen, F.L., 1966. Thinning effects of bloom time gibberellic sprays on Thompson seedless table grapes. Am J. Enol. Vitic. 17, 283-289.

Marschner, H., 1999. Function of Mineral Nutrients: Micronutrients. In: Mineral Nutrition of Higher Plants. (Academic Press: San Diego San Francisco New York Boston London Sydney Tokyo) pp. 229-434.

May, P., 2004. Flowering and Fruitset in Grapevines, Lythrum, Adelaide.

McGuire, L. \& Moulds, G., 2009. Mothballing the Vineyard - Actions and Impacts, Final Report for Grape and Wine Research \& Development Corporation, Murray Valley Winegrowers' Inc. pp. 1-97.

Mollah, M.\& Krstic, M., 2000. Adoption of Mechanised Dried Vine Fruit Production Systems, Final Report for Dried Fruit Research and Development Council, Department of Natural Resources and Environment Council, pp. 1-60.

Naito, R., Yamamura H., Takashima K. \& Koba, F., 1985. Effects of Denapon and Ethrel on thinning grapes. Sci. Hortic. 25, 61-69.

Rahemi, M.\& Ramezanian, A., 2007. Potential of ethephon, NAA, NAD and urea for thinning pistachio fruitlets. Sci. Hortic. 111, 160-163.

Raven, P.H., Evert R.F. \& Eichhorn, S.E., 1992. Regulating Growth and Development: The Plant Hormones. In: Plant Physiology. P.H. Raven, R.F. Evert, S.E. Eichhorn. (Eds.) (Worth Publishers: New York) pp. 545-572.

Robinson, J.B,. 1988. Grapevine Nutrition. In: Viticulture. B.G. Coombe, P.R. Dry. (Eds.) Wine titles, Adelaide. pp. 178-209.

Salisbury, F.B. \& Ross, C.W., 1992. Ethylene, a Volatile Hormone. In: Plant Physiology. Carey, J.C. (ed). Wadsworth, Belmont, California. pp. 382-407

Sarooshi, R.A. \& Roberts, E.A., 1979. Effects of trellising, crown bunch handling, and the number of oil emulsion and gibberellic acid sprays on harvest-pruned sultanas. Australian J. of Exp. Agric. 19, 122-128.

Shah, J., 2003. The salicylic acid loop in plant defense. Curr. Op. Plant Biol. 6, 365-371.

Shaw, I., Mollah M., Hancock, F. \& Braybrook D., 2000. Shaw Swingarm Trellis Maximum Mechanisation in Trellis Dried Grape Production. Department of Natural Resources and Environment, Mildura, Victoria, pp 11-19.

Sommer, K. J., Hancock, E. A. \& Downey, M. O., 2010.Survival and recovery of Chardonnay (Vitis vinifera) under minimum irrigation with or without fruit removal. Grape grower and Vignerons, May 2010, 20-21.

Srinivasan, C. \& Mullins, M.G., 1980. Effects of Temperature and Growth Regulators on Formation of Anlagen, Tendrils and Inflorescences in Vitis vinifera $\mathrm{L}$. Annals of Botany 45, 439-446.

Swain, S.M. \& Singh, D.P., 2005. Tall tales from sly dwarves: novel functions of gibberellins in plant development. Trends Plant Sci. 10, 123129.

Szyjewicz, E. \& Kliewer, M.W., 1983. Influence and timing of ethephon application on yield and fruit composition of Chenin blanc grapevines, Am. J. Enol. Vitic. 34, 53-56.

Szyjewicz, E., Rosner, N. \& Kliewer, W.M. 1984. Ethephon ((2-Chloroethyl) phosphonic Acid, Ethrel, CEPA) in Viticulture - A Review. Am. J. Enol Vitic. 35, 117-123. 
Tse, A.T.Y., Ramina, A., Hackett, W. \& Sachs, R., 1974. Enhanced Inflorescence Development in Bougainvillea "San Diego Red" by Removal of Young Leaves and Cytokinin Treatments. Plant Physiol. 54, 404-407.

Weaver, R. 1975. Effect of time of application of potassium gibberellate on cluster development of 'Zinfandel' grapes. Vitis 14 97-102.

Weaver, R. \& Pool, R.M. 1969. Effect of Ethrel, Abscisic Acid, and a Morphactin on Flower and Berry Abscission and Shoot Growth in Vitis vinifera. J. Am. Soc. Hortic. Sci. 94, 474-478.

Weaver, R.J. \& Pool, R.M. 1968. Induction of Berry Abscission in Vitis Vinifera by Morphactins. Am. J. Enol. Vitic. 19, 121-124.

Weaver, R.J. \& Pool, R.M., 1971a. Chemical thinning of grape clusters (Vitis vinifera L.). Vitis 10, 201-209.
Weaver, R.J.\& Pool, R.M., 1971b. Effect of Ethephon and A Morphactin on Growth and Fruiting of 'Thompson Seedless' and 'Carignane' Grapes. Am. J. Enol. Vitic. 22, 234-239.

Weaver, R.J., Van Overbeek, J. \& Pool, R.M., 1965. Induction of Fruit Set in Vitis vinifera L. by a Kinin. Nature 206, 952-953.

Wittwer, S.H. \& Teubner, F.G., 1959. Foliar Absorption of Mineral Nutrients. Ann. Rev. Plant Physiol. 10, 13-30.

Zabadal, T.J., VanEe, G.R., Dittmer, T.W. \& Ledebuhr, R.L., 1996. Evaluation of Chemical Crop Adjustment Methods for Mechanically Pruned 'Concord' Grapevines. In: Henick-Kling, T., Wolf, T.E. \& Harkness, E.M. (eds). Proc. $4^{\text {th }}$ International Symposium on Cool Climate Viticulture and Enology, July 1996, Rochester, New York. pp. 18-23. 